\title{
Politik Pengakuan Perempuan dengan Disabilitas \\ Pasca Bencana Gempa di Yogyakarta
}

Oleh

\author{
Fina Itriyati dan Desintha Dwi Asriani ${ }^{1}$
}

\begin{abstract}
Abstrak
Penelitian ini merupakan studi awal mengenai politik pengakuan perempuan dengan disabilitas pasca bencana gempa 2006 di Kabupaten Bantul dan Klaten, Yogyakarta dan Jawa Tengah. Dalam studi awal ini ditemukan adanya transformasi gerakan disabilitas pasca bencana di kedua daerah tersebut. Penulis ingin menggarisbawahi bahwa peran perempuan dengan disabilitas baru bisa mendorong adanya transformasi gerakan perempuan dengan disabilitas. Perubahan tersebut bisa dilihat dari berbagai sisi dimana sebelum gempa terjadi, wacana perempuan dengan disabilitas hanya dilihat sebagai tragedi personal dimana persoalan disabilitas dilihat sebagai masalah individu sehingga pendekatan yang dipakai untuk menangani kelompok mereka hanya sebatas charity, pemberian pelatihan-pelatihan yang sifatnya klinis dengan tujuan supaya mereka bisa kembali seperti orang normal dan punya kemandirian hidup. Setelah gempa, muncul banyak DPO (Disabled People Organization) dan perkumpulan yang menjadi organisasi bagi para penyandang disabilitas tidak hanya mereka yang menjadi korban gempa, tetapi juga penyandang disabilitas lama bukan karena gempa yang selama ini disembunyikan oleh keluarganya dan terpinggirkan dalam pergaulan sosial. Mereka muncul untuk coming out dan memberi pelajaran bagi masyarakat bahwa perbedaan merupakan hal yang biasa dan proyek normalisasi merupakan sesuatu yang berhak untuk ditolak jika tidak diinginkan oleh mereka. Bahkan mereka juga sudah mampu untuk mengkounter wacana gerakan perempuan mainstream bahwa mereka juga berhak untuk diakomodasi kepentingannya, dimana perempuan dengan disabilitas mempunyai hak yang sama dengan perempuan lainnya secara universal. Studi awal yang dilakukan dengan metode penelitian kualitatif dengan pendekatan etnografi ini merupakan preliminary study yang masih berproses dengan penelitian selanjutnya.
\end{abstract}

Kata kunci: perempuan dengan disabilitas, gempa bumi, politik pengakuan, DPO (Disabled People Organization), model individual dan model sosial disabilitas

\begin{abstract}
This study is a preliminary study of the politics of recognition of women with disabilities in the aftermath of the 2006 earthquake in Bantul and Klaten, Yogyakarta and Central Java. In this preliminary study, it is found that there is transformation in the disability movement in both regions. The authors would like to underline that the role of new women with disabilities affected by earthquake can encourage the

\footnotetext{
${ }^{1}$ Fina Itriyati adalah staf pengajar Departemen Sosiologi Fisipol Universitas Gadjah Mada. Desintha Dwi Asrianii menyelesaikan studi S1 dan S2 di Sosiologi di Universitas Gadjah Mada, saat ini adalah staf pengajar di Jurusan sosiologi Fisipol UGM.
} 


\section{Jurnal Pemikiran Sosiologi Volume 1 No. 2, 2012 \\ Politik Pengakuan Perempuan dengan Disabilitas Pasca Bencana Gempa di Yogyakarta \\ Fina Itriyati dan Desintha Dwi Asriani}

transformation of the women with disabilities' movement. These changes can be seen from all sides which before the earthquake, the discourse of women with disabilities are seen as a personal tragedy wher edisability issues are seen as an individual problem. The common approach used to deal with them is a charity activities, training services that are clinically aimed to make them as normal people and have independent lives. After the earthquake, there are a lot of DPO (Disabled People Organization) and association sfor persons with disabilities which accomodate not just those affected by the earthquake, but also all persons with disabilities who had been hidden by their families and socially marginalized. They appear to becoming out and giving a lesson to the people that the differences are common and normalization project is a choice that they have rights to refuse if it is not desired by them. In fact, they also have been able to counter the mainstream women's movement discourse that their interests are also entitled to be accommodated in universal women's discourse. This preliminary study which conducted by qualitative research methods with an ethnographic approach is still very early and still continuing with further research.

Keywords: women with disabilities, earthquake, politics of recognition, DPO (Disabled People Organization), individual and social model of disabilities

\section{A. Latar Belakang}

Bencana gempa yang terjadi pada bulan Mei tahun 2006 sudah berlalu. Program-program rekonstruksi dan intervensi juga sudah dilakukan. Mayoritas lembaga-lembaga non pemerintah baik itu nasional dan internasional yang pada masa tanggap darurat, rehabilitasi dan rekonstruksi saling bekerja sama membantu memulihkan keadaan di titik-titik bencana sudah meninggalkan Yogyakarta dan Klaten, Jawa Tengah. Lembaga-lembaga tersebut mengalihkan program intervensi mereka di daerah lain yang lebih membutuhkan prioritas bantuan.

Bangunan infrastruktur yang baru, rumah, fasilitas pendidikan, kesehatan serta fasilitas pelayanan publik yang lain sudah dianggap cukup untuk melayani penduduk di kantong bencana dan menggantikan bangunan yang lama dengan tingkat kerusakan infrastruktur yang parah. Tingkat kerusakan dan kerugian infrastruktur tersebut diperkirakan sejumlah 29, 129 milyar rupiah dan korban jiwa sekitar 5.716 orang dan korban luka berat sebanyak 37.927 jiwa (Budisusila, 2007).

Pada saat dan setelah gempa terjadi, kelompok perempuan, anak-anak dan lanjut usia menjadi kelompok yang paling rentan dalam menerima resiko terburuk akibat gempa. Dikarenakan tingkat kerentanan dan dinamika yang terjadi dalam ketiga kelompok tersebut berbeda, penulis akan secara spesifik memfokuskan pada kelompok perempuan rentan yaitu kelompok perempuan dengan disabilitas. $^{2}$ Menurut Fatimah (2007), perempuan

\footnotetext{
2 Istilah "orang dengan disabiltas" atau "penyandang disabilitas" merupakan konsep baru yang muncul setelah disahkannya Undang-Undang Hak Penyandang Disabilitas No 19 tahun 2011 pada tanggal 18 Oktober 2011 yang merupakan ratifikasi dari penandatanganan Convention on the Right of Persons with Disabilities (Konvensi mengenai Hak-Hak Penyandang Disabilitas) oleh Pemerintah RI pada tanggal 30 Maret 2007 di New York. Dalam tulisan ini konsep penyandang disabilitas bisa dipertukarkan dengan konsep orang dengan disabilitas atau disabel. Konsep Orang dengan Disabilitas menjadi konsep baru setelah sebelumnya konsep penyandang cacat berubah menjadi
} 
Jurnal Pemikiran Sosiologi Volume 1 No. 2, 2012

Politik Pengakuan Perempuan dengan Disabilitas Pasca Bencana Gempa di Yogyakarta

Fina Itriyati dan Desintha Dwi Asriani

banyak menjadi korban gempa baik itu meninggal dunia maupun korban dengan luka berat karena pada saat gempa terjadi, mereka banyak yang sedang berada di dapur untuk menyiapkan makanan untuk keluarga. Sementara itu, akses untuk menyelamatkan diri keluar rumah relatif jauh karena dalam konstruksi rumah di masyarakat Jawa, letak dapur berada di bagian paling belakang dari struktur rumah. Lebih jauh lagi, kondisi bangunan dapur relatif lebih buruk dan lebih rentan untuk ambruk dibanding dengan bangunan lain di dalam rumah seperti kamar tidur dan ruang tamu sehingga perempuan menjadi korban karena tidak sempat menyelamatkan diri. Pun ketika sedang tidak berada di dapur, perempuan pasti sedang berusaha menyelamatkan anak-anaknya sebelum menyelamatkan diri mereka sendiri sehingga waktu yang diperlukan untuk bisa selamat dari bencana tersebut semakin panjang sehingga banyak dari mereka dan anak-anak menjadi korban.

Setelah gempa berlalu, mereka harus menghadapi banyak tantangan karena hidup harus terus berjalan meskipun mereka tidak lagi hidup yang selengkap seperti sebelumnya. Rumah yang belum selesai dibangun, kesulitan untuk mendapatkan air bersih sementara makanan yang sehat dan gizi yang baik untuk anak-anak yang harus selalu dicukupi, Sementara itu, perempuan juga tetap harus bekerja keras bersama suami untuk menghidupi

konsep difabel (different ability) yang meskipun istilah tersebut lebih halus dari istilah sebelumnya, namun masih mangandung stigma yang melekat bagi penyandangnya.

${ }^{3}$ Paraplegia merupakan kondisi kecacatan bagi seseorang yang mengalami kelumpuhan pada bagian bawah tubuh mereka akibat cedera pada sumsum tulang belakang. Cedera ini disebabkan oleh berbagai hal semisal kecelakaan lalu lintas, jatuh dari ketinggian, tertimpa benda berat atau karena suatu penyakit. Cedera pada keluarganya. Bagi mereka yang selamat, belum tentu hidup menjadi mudah karena banyaknya bantuan berdatangan. Mereka yang selamat tetapi harus mengalami perubahan fungsi tubuh akibat tertimpa bangunan atau barang berat akibat gempa harus menghadapi dampak akibat kondisi tubuhnya yang cacat seumur hidup mereka. Kualitas hidup yang prima sebelum gempa menjadi turun drastis karena kondisi kelumpuhan atau kehilangan anggota tubuh menjadikan kehidupan mereka sehari-hari lebih sulit dijalani. Perempuan dengan paraplegia ${ }^{3}$ sangat sulit untuk hidup tanpa bantuan orang lain karena kelumpuhan yang mereka alami sementara akses dan peluang untuk bisa hidup mandiri di lingkungan mereka sangat bias normal. Semua fasilitas publik tidak memungkinkan mereka bisa mengaksesnya, bahkan yang lebih buruk, konstruksi rumah mereka sendiri juga tidak memungkinkan bagi mereka untuk bisa melakukan semuanya dengan mandiri. Dimulai dari pintu rumah yang tidak bisa diakses kursi roda, kamar mandi yang berundak dan pintu yang sempit sehingga juga tidak memungkinkan bagi penyandang disabilitas untuk melakukan aktivitas paling pribadi sekalipun secara mandiri.

Perempuan dengan disabilitas mengalami penderitaan yang berlapis karena ketika mereka menjadi korban hidup, mereka harus menghadapi banyak adaptasi karena kemampuan tubuhnya yang tidak lagi seperti dulu. Dengan menjadi penyandang

sumsum tulang belakang yang mengenai sistem saraf pusat tidak hanya menyebabkan kelumpuhan pada kedua tungkai saja,namun juga seluruh sistem tubuh dibawah level cedera ikut terganggu. Pada beberapa kasus, penderita paraplegia masih dapat berjalan meski tidak bisa dalam jangka waktu yang lama. Sebagian besar penderitanya bergantung pada kursi roda atau alat penunjang lainnya. Impotensi dan ketidakmampuan mengontrol buang air merupakan hal yang umum dialami oleh penderitanya (news-medical.net) 
Jurnal Pemikiran Sosiologi Volume 1 No. 2, 2012

Politik Pengakuan Perempuan dengan Disabilitas Pasca Bencana Gempa di Yogyakarta

Fina Itriyati dan Desintha Dwi Asriani

disabilitas mereka harus berhadapan dengan banyak stigma dan pengalaman yang menyulitkan mereka untuk melanjutkan hidup. Banyak yang menderita depresi dan trauma psikologis yang sulit untuk dilupakan dari memori bahkan kasus percobaan bunuh diri menjadi kasus yang umum didengar dari penyandang disabilitas baru korban bencana tersebut. Perempuan-perempuan tersebut juga harus rela ditinggalkan pasangannya karena stigma ketidakmampuan mereka untuk melakukan aktivitas seksual begitu melekat. Hasil penelitian yang dilakukan oleh lembaga SAPDA (Sentra Advokasi Perempuan, Difabel dan Anak) sejak tahun 2009 sampai dengan 2011 (Andriani, 2011) menyebutkan bahwa hampir semua perempuan yang menikah dan menjadi penyandang disabilitas karena gempa ditinggalkan oleh pasangannya baik itu secara resmi maupun dikembalikan ke keluarganya tanpa kejelasan status. Mereka yang tidak ditinggalkan pasangannya kerap menerima kekerasan dalam rumah tangga dan dieksploitasi secara ekonomi oleh suaminya karena mereka mendapatkan bantuan sosial secara rutin dari pemerintah dan dari lembaga sosial lainnya. Penelitian tersebut menyebutkan bahwa dari 7 responden yang belum menikah ketika menjadi disabel baru, hanya 1 perempuan yang tidak ditinggalkan oleh pasangannya dan menikah pada tahun 2011. Perempuan disabel baru tersebut harus menghadapi kenyataan pahit barlapis bahwa mereka tidak lagi bisa beraktivitas secara mandiri, ditinggalkan pasangan yang tidak mau bertanggung jawab terhadap keluarga serta anak-anak yang harus ditopang hidupnya. Sementara bagi perempuan-perempuan tersebut, bekerja di luar merupakan hal yang mustahil karena akan membutuhkan banyak bantuan dari orang lain dan tentu saja biaya yang tidak sedikit agar memungkinkan mereka untuk melakukan mobilitas seperti misalnya membeli sepeda motor roda tiga, kursi roda yang ringan dan alat bantu yang lainnya. Mereka harus beradaptasi sekaligus dengan tubuhnya, dengan kenyataan baru sebagai orang tua tunggal dan sebagai tiang ekonomi bagi keluarganya.

Prakteknya, mereka harus berjuang setiap hari untuk bertahan dan berdaptasi dengan kondisi tubuh mereka dan berjuang untuk bertahan hidup. Mereka dengan kehilangan kemampuan bekerjanya harus menghadapi banyak hambatan karena kondisi tubuh mereka. Mereka harus terus hidup tidak hanya untuk diri sendiri tetapi juga berpikir bagaimana harus menghidupi anak-anak mereka serta berpikir setiap saat bagaimana mendapatkan kelangsungan medikalisasi bagi tubuh mereka serta asuransi kesehatan yang bisa digunakan setiap waktu oleh mereka karena praktis dengan menjadi penyandang disabilitas mereka harus selalu menghadapi masalah kesehatan yang menuntut pada pemenuhan jaminan kesehatan mereka secara jangka panjang. Disamping masalah dalam hal pemenuhan kebutuhan dasar, mereka juga harus menghadapi masalah berkaitan dengan adaptasi mereka dengan kondisi tubuh yang berbeda, bagaimana menggunakan alat-alat bantu untuk secara mandiri, berinteraksi serta menggunakan fasilitas publik dan lain-lain.

Pasca gempa, mereka menerima banyak bantuan dari pemerintah maupun dari LSM lokal maupun internasional. Terkadang, mereka juga mendapatkan bantuan lainnya dari sumber dana yang lain seperti donatur, perkumpulan- 
Jurnal Pemikiran Sosiologi Volume 1 No. 2, 2012

Politik Pengakuan Perempuan dengan Disabilitas Pasca Bencana Gempa di Yogyakarta

Fina Itriyati dan Desintha Dwi Asriani

perkumpulan yang peduli terhadap

keberlangsungan dan kesejahteraan hidup mereka yang menjadi penyandang disabilitas. Programprogram pemberdayaan dan intervensi juga banyak dilakukan tidak hanya untuk disabel baru tetapi juga untuk disabel bukan korban gempa. Namun, setelah program-program pemberdayaan dan intervensi tersebut selesai, bagaimana dengan bagaimana kualitas dan kelangsungan hidup mereka belum banyak diteliti lebih jauh.

Sebagian besar perempuan penyandang disabilitas sangat tergantung dengan keluarga besar mereka. Ketika pasangan meninggalkan mereka, mereka bergantung kepada simpati keluarga besar agar bisa bertahan hidup. Meskipun mereka mendapatkan bantuan berupa pelatihan-pelatihan dan alat kerja baik itu dari pemerintah maupun dari LSM lokal dan internasional,namun kenyataannya modal dan bisnis yang dijalankan tidak dapat bertahan lama. Kebanyakan yang mendapatkan alat kerja berupa komputer tidak lagi mendapatkan pelanggannya karena sebagian besar masyarakat sudah menggunakan komputer jinjing karena harganya yang terjangkau. Mereka yang mendapatkan alat menjahit dan ketrampilannya juga tidak dapat bertahan karena masyarakat sekarang lebih suka membeli pakaian jadi yang lebih murah dan jika mendapatkan order, mereka dibayar dengan sangat murah dan kebanyakan juga tidak sanggup untuk memenuhi pesanan partai besar. Sementara itu, kebutuhan hidup menuntut untuk terus dipenuhi, termasuk membayar sekolah anak-anak, membeli peralatan sekolah serta kebutuhan membeli obatobatan untuk perawatan rutin kesehatan mereka. Bagi mereka yang berasal dari keluarga menengah ke atas tidak mengalami masalah seperti diatas, sementara bagi keluarga miskin, karena mereka tidak dapat terus menerus bergantung pada keluarga besarnya mereka lalu menempuh jalan dengan menjual apa saja untuk bisa bertahan hidup.

Kelompok orang dengan disabilitas merupakan bagian dari kelompok masyarakat yang tertindas dan terstigma seperti yang dikatakan oleh Bishop (dalam Mullaly, 2002) bahwa kelompok tertindas selalu dilekatkan paling tidak satu mitos seksual negatif seperti tidak bisa mengontrol nafsu seksualnya, tidak bermoral atau terbelakang. Lebih spesifik lagi bagi penyandang disabilitas, mereka dipandang sebagai kelompok yang pasif, tidak produktif dan digolongkan sebagai kelompok orang tanpa seksualitas. Penyandang disabilitas juga direpresentasikan sebagai kelompok tanpa gender, makhluk aseksual, aneh dan tidak normal (Meekosha, 2004). Mayoritas orang dalam masyarakat juga masih memandang disabilitas sebagai penyakit sehingga sangat umum terjadi ketika mereka melihat orang dengan disabilitas selalu diasosiasikan sebagai kelompok dengan sebutan-sebutan negatif yang selalu bergantung dan membutuhkan pertolongan orang lain (Edwards, 2004). Perempuan dengan disabilitas mengalami penindasan dan diskriminasi berlapis karena mereka disabel, karena mereka perempuan sehingga ketika tidak produktif dianggap tidak normal, dan karena mereka berasal dari kelompok masyarakat miskin. Dalam konteks perempuan dengan disabilitas sebagai korban bencana gempa, mereka harus menghadapi banyak peristiwa yang mengguncang hidup mereka seperti kehilangan keluarga dekat, anak-anak sampai kehilangan anggota tubuh mereka yang menyebabkan mereka kehilangan kemampuan bekerja. 
Jurnal Pemikiran Sosiologi Volume 1 No. 2, 2012

Politik Pengakuan Perempuan dengan Disabilitas Pasca Bencana Gempa di Yogyakarta

Fina Itriyati dan Desintha Dwi Asriani

Namun, dibalik semua bencana yang terjadi, ternyata kelompok perempuan dengan disabilitas akibat korban gempa bisa memberi warna bagi gerakan disabel secara umum di Yogyakarta. Penyandang disabilitas akibat gempa di Bantul dan Klaten membentuk banyak organisasi dan perkumpulan yang tujuannya membantu anggota kelompoknya mulai dari strategi dalam pemenuhan ekonomi, membantu memecahkan masalah domestik, serta problem lainnya termasuk bagaimana mendapatkan perhatian publik mengenai disabilitas serta melakukan pengarusutamaan disabilitas dalam masyarakat lebih luas. Organisasi-organisasi tersebut mayoritas diketuai oleh perempuan dan itu memberi dampak yang signifikan bagi perubahan sosial dibandingkan dengan situasi sebelum bencana terjadi. Sebelum bencana terjadi, organisasi penyandang disabilitas tersentral dalam Yayasan Persatuan Penyandang Cacat Indonesia (PPCI) dan semua distribusi bantuan dari pemerintah serta kegiatannya terpusat pada yayasan tersebut. Setelah gempa, banyak organisasi dan perkumpulan penyandang disabilitas bermunculan dan menjadi wadah bagi disabel untuk menyuarakan kepentingannya. Tidak hanya penyandang disabilitas baru yang bergabung dalam organisasi dan perkumpulan-perkumpulan tersebut, tetapi disabel lama bukan korban gempa

4 Pusat Rehabilitasi YAKKUM adalah sebuah lembaga non pemerintah, organisasi sosial Kristen yang merupakan bagian dari YAKKUM (Yayasan Kristen Untuk Kesehatan Umum). Pusat Rehabilitasi YAKKUM memberikan pelayanan kepada para penyandang disabilitas (yakkumrehabilitation.org)

5 KARINAKAS (Karitas Indonesia Keuskupan Agung Semarang) adalah sebuah lembaga kemanusiaan di bawah naungan Keuskupan Agung Semarang yang memberi perhatian lebih pada difabel, pengurangan risiko bencana, dan pemberdayaan ekonomi masyarakat tanpa dibatasi juga merasa tersuarakan aspirasinya yang selama ini terbungkam karena diskriminasi dan marginalisasi yang dilakukan oleh keluarga dan masyarakat. Perempuan disabel merasa mengalami kondisi yang lebih baik sejak bergabung dalam DPO (Disabled People Organization). Saat ini, ada 8 DPO dan 2 koperasi yang dibentuk oleh Yakkum ${ }^{4}$ dan masih berlangsung kegiatannya. Sementara itu, masih banyak paguyuban penyandang disabilitas lainnya yang mempunyai kegiatan inti memberdayakan anggota-anggotanya yang merupakan penyandang disabilitas. Selain Yakkum, LSM lainnya seperti KARINAKAS 5 dan SAPDA ${ }^{6}$ juga mempunyai kegiatan yang serupa yang memberi perhatian terhadap penyandang disabilitas. Setelah program pemberdayaan dan intervensi tersebut selesai, organisasi dan paguyuban tersebut menjadi organisasi independen yang mengusahakan kegiatan dan pendanaannya sendiri tanpa supervisi dari lembaga payung. Mereka berjuang demi hakhak mereka sebagai warga yang utuh, memberikan pelayanan untuk teman sesama penyandang disabilitas, memberikan kredit atau bantuan keuangan, mengusahakan asuransi kesehatan bagi kelompok mereka serta ikut membantu menyelesaikan persoalan yang dihadapi penyandang disabilitas seperti persoalan rumah tangga, mengusahakan alat bantu untuk

sekat agama, suku, ras, dan kepentingan. Sejak bencana gempa Yogyakarta 2006, KARINAKAS terus bergulat bersama masyarakat di wilayah Jateng - DIY dalam pemberdayaan difabel, pengurangan risiko bencana, dan pengembangan ekonomi masyarakat lemah.

${ }^{6}$ LSM yang bergerak dalam advokasi kebijakan di tingkat daerah, pendidikan, pendampingan dan pemberdayaan terhadap perempuan, difabel dan anak khususnya dalam sektor kesehatan dan pendidikan di Daerah istimewa Yogyakarta. 
Jurnal Pemikiran Sosiologi Volume 1 No. 2, 2012

Politik Pengakuan Perempuan dengan Disabilitas Pasca Bencana Gempa di Yogyakarta

Fina Itriyati dan Desintha Dwi Asriani

mempermudah mobiltas maupun dalam berkegiatan sehari-hari. Sebagai kelompok disabel baru, ternyata kegiatan mereka bisa memberi warna dalam mengadvokasi kepentingan seluruh penyandang disabilitas di Yogyakarta. Jaringan mereka juga mampu memberikan kekuatan sebagai kelompok yang diakui eksistensinya dan mampu memperjuangkan anggotanya dalam mengakses haknya ke pemerintah dan mengadvokasi kepentingan mereka termasuk dalam melakukan pengarusutamaan disabilitas dalam gerakan perempuan di Yogyakarta. Tulisan ini akan melihat sejauh mana praktek politik pengakuan perempuan dengan disabilitas pasca gempa terutama setelah tahapan rekonstruksi dan rehabilitasi selesai dilakukan. Tulisan ini juga hendak mengkaitkan bagaimanapola gerakan perempuan dengan disabilitas ini dalam mengkounter marginalisasi terhadap kelompok mereka ditengah gerakan perempuan mainstream di Yogyakarta.

\section{B. Absennya Isu Disabilitas dalam Gerakan Perempuan}

Diskusi mengenai gender dalam konteks perempuan difabel tampaknya memang belum menjadi wacana yang populer. Meskipun gender memposisikan dirinya sebagai kajian partikular sebagai sebuah kontras atas mainstream-mainstream universal namun masyarakat akan lebih mudah jika mencari kedalaman isu gender tentang peran sosial, politik, ekonomi, seksualitas dibandingkan dengan pembahasan yang lebih menukik tentang perempuan disabel. Padahal jika hendak merujuk pada teori peran West dan Zimmerman (1987), maka hampir dapat dikatakan bahwa tidak ada satu orang pun yang akan luput dari sosialisasi gender. Sosialisasi gender yang terjadi melalui berbagai mekanisme berlapis, mulai dari keluarga, masyarakat hingga negara akan senantiasa menghadirkan individu sebagai subjeknya. Oleh karena itu pada setiap pola interaksi dapat dipastikan akan muncul sebuah persoalan yang terkait dengan gender seperti dalam tarik menarik kekuasaan, hubungan berbasis kekerasan hingga komodifikasi tubuh. Menariknya, di berbagai bentuk dinamika interaksi gender tersebut, perempuan justru sering menjadi pihak yang akan teridentifikasi sebagai korban. Mengapa? Sebab konstruksi sosial yang sampai saat ini semakin menimbulkan kegamangan karena belum juga berakhir, perempuan sering ditempatkan pada posisi minor atau subordinat.

Dalam struktur patriarkhis, kehadiran perempuan hanya dijadikan sebagai pelengkap atau peyongkong setiap kegiatan utama yang sama sekali menutup peluang-peluang untuk berdaya. Sebagai contoh, dalam kehidupan keluraga, anak-anak perempuan akan cenderung mendapatkan pola pengasuhan domestik dengan harapan dapat menjadi pendamping dan pengasuh yang berkarakter serupa dengan internalisasi nilai seperti kepatuhan dan kelemahan. Implikasi konkritnya adalah, perempuan tidak dianjurkan memiliki ambisi untuk bersekolah tinggi, berwawasan luas atau berkarakter keras sebagai pemimpin. Sehingga pada periode pertumbuhan jangka panjang, perempuan akan semakin matang untuk menjadi pengikut lakilaki-penguasa-pemilik keputusan. Demikian halnya di ranah publik yang terkenal dengan feminisasi kerjanya. Perempuan hanya seolah-olah telah keluar 
Jurnal Pemikiran Sosiologi Volume 1 No. 2, 2012

Politik Pengakuan Perempuan dengan Disabilitas Pasca Bencana Gempa di Yogyakarta

Fina Itriyati dan Desintha Dwi Asriani

dari kungkungan diskriminatif, namun sebetulnya masuk dalam perangkap domestifikasi dalam ruang baru bernama publik.

Pada kondisi yang dikatakan 'normatif' untuk tidak melakukan dikotomi atas normal dan tidak normal, maka keberadaan perempuan disabel menjadikan sebuah refleksi besar. Masih dalam konteks peran sosial, Goffman (dalam Gerschick, 2000) menggarisbawahi bahwa disabilitas bukan hanya persoalan fisik atau mental namun juga terkait dengan relasi sosial dan stigma. Manusia dengan disabilitas cenderung akan mendapatkan sangkaan buruk dari orang lain seperti cacat, abnormal, bahkan gila. Mereka didiskriminasi atas kondisi yang tidak serupa dengan kebanyakan orang sehingga sering dikategorikan sebagai yang lain atau tidak terdaftar sebagai subjek dalam keseharian. Demikian halnya dalam peran gender, dimana labelitas terlekat pada proses interaksi sehari-hari, maka legitimasi atas maskulin dan feminin sering lahir dari konstruksi yang diberikan oleh orang lain seiring dengan stigma yang terjadi.

Dalam ranah keluarga, kepemilikan seseorang atas gendernya juga menjadi bersarat dan sekali lagi sangat ditentukan oleh kekuasaan orang lain atau dalam hal ini orang tua. Gerschick (2000) mencontohkan bahwa anak yang lahir dengan disabilitas bawaan maka orang tua atau orang-orang yang ada di sekitarnya akan menetapkan anak tersebut dalam kategori jenis kelamin teretntu namun tidak memiliki ekspektasi terhadap peran gendernya. Berbeda dengan anak-anak yang memiliki kondisi disabilitas ringan seperti ketidakmampuan melihat (buta), maka para orang tua akan memiliki harapan yang besar untuk mensosialisasikan dan menginternalisasikan peran gender tertentu terhadap anak tersebut. Anak-anak dengan disabilitas cenderung sulit untuk mendapatkan peluang dalam memahami konstruksi maupun realitas peran gender bahkan memiih sendiri peran gendernya karena persoalan stigma yang hampir menjadi bagian kehidupannya menjadi penghalang tersendiri untuk keluar menjadi individu yang bebas. Meskipun teori gender mengarahkan agar setiap orang memiliki peluang yang sama untuk mempelajari, memahami dan merespon tentang konstruksi peran gender yang disosialisaikan namun perlu digarisbawahi bahwa derajat kesempatan bagi anak-anak disabel jauh lebih terbatas dibandingkan yang bukan disabel.

Studi tentang gender dan disabilitas pada akhirnya sama-sama memberikan tekanan pada isu diskriminasi dan akses atas pemenuhan hak dasar. Oleh karena itu dalam agenda perjuangan sebetulnya dua hal tersebut memiliki ruh dan spirit yang serupa dalam melihat, memahami dan menerjemahkan kelompok-kelompok rentan. Namun ternyata, dalam prakteknya, kasus-kasus perempuan disabel tidak cukup hanya dapat dijelaskan dengan pendekatan-pendekatan disabilitas. Hal ini disebabkan oleh persoalan berlapis yang dimiliki oleh perempuan disabel dibanding perempuan bukan disabel dan laki-laki disabel. Gerschick (2000) menuliskan bahwa meskipun laki-laki dan perempuan memiliki pengalaman yang serupa tentang marginalisasi, isolasi dan diskriminasi namun variasi atas jumlah ketidakbaikan tersebut mengantarkan mereka pada porsi analisis yang berbeda. Misalnya, perempuan disabel menjadi lebih rentan untuk menjadi sasaran perkosaan atau pelecehan seksual. Hal ini dikarenakan konstruksi berlapis yang dilekatkan. 
Jurnal Pemikiran Sosiologi Volume 1 No. 2, 2012

Politik Pengakuan Perempuan dengan Disabilitas Pasca Bencana Gempa di Yogyakarta

Fina Itriyati dan Desintha Dwi Asriani

Perempuan dasarnya dianggap lemah akan semakin disangka tidak memiliki arti apapun ketika didapati kondisi tubuhnya dalam kategori disabel. Secara ekstrim, perempuan dengan disabilitas hanya akan dimaknai sebagai objek atau benda yang tidak bermanfaat selain alat pemuas pihak lain yang lebih berkuasa.

Secara teoritis, pendekatan gender dan feminisme telah berupaya untuk mencapai seluruh ranah yang menjadi bagian dari interaksi gender. Chafetz (1999) misalnya, dalam Handbook of the Sociology of Gender juga telah menurunkan beberapa pendekatan gender hampir ke dalam ritual keseharian masyarakat dalam berinteraksi. Penjelasan teori yang paling mendekati adalah yang disebutkan Kronenfeld (1999) tentang penyakit mental. Namun penjelasan tersebut hanya terbatas pada argumentasi tentang perbedaan status penyakit mental antara perempuan dan laki-laki. Disebutkan bahwa jumlah pengidap penyakit mental antara laki-laki dan perempuan lebih disebabkan oleh perbedaan beban peran gender yang dibebankan oleh struktur masyarakat. Akan tetapi hal tersebut belum cukup memberikan sumbangsih teori pada dinamika perempuan disabel. Selain ada istilah yang juga masih diskriminatif yakni 'penyakit' (illness), berbagai masalah-masalah yang mungkin menjadi bagian dari perempuan dengan disabilitas sama sekali belum nampak.

Dalam unit terkecil keluarga, melalui catatan Bielby (1999) dijelaskan tentang pola perubahan yang terjadi dalam relasi rumah tangga antara terkait dengan kehadiran pola ekonomi modern dimana kemudian sebuah keseimbangan hubungan diterjemahkan melalui pembagian kerja antara laki- laki dan perempuan. Sayangnya, dikotomi ini justru membatasi perempuan dalam mengartikulasikan pilihan-pilihan-nya sebagai manusia. Namun lebih jauh menjelaskan tentang relasi yang terjadi pada perempuan dengan disabilitas juga masih belum nampak. Padahal unit keluarga merupakan sebuah organisasi kecil dalam lingkungan masyarakat yang memiliki porsi dominan dalam membentuk nilai serta pola perilaku setiap individu.

Demikian halnya ketika masuk pada ruang politik yang dianggap sebagai arena yang lebih menjanjikan bagi setiap individu untuk menegosiasikan kepentingan atas keberadaanya sebagai agency. Tanpa terkecuali perempuan, area politik ini menjadi sasaran penting yang harus diagendakan agar perempuan tidak lagi diabaikan dari proses perumus kebijakan hingga eksekusi pengambilan keputusan. Esterchild (1999) berargumentasi bahwa absennya perempuan dalam percaturan politik sudah jelas bahwa memang ada konstruksi yang dimainkan secara sosial dan budaya untuk mengukuhkan anggapan bahwa perempuan tidak layak untuk dipasangkan dengan laki-laki dalam kemampuan berpolitiknya. Perempuan terlalu sulit untuk beradaptasi karena kewajiban-kewajiban domestik yang dilekatkan. Adanya wacana bias tersebut yang menjadi dasar kuat untuk mendobrak berbagai batasan agar perempuan mulai dapat diperhitungkan. Di Indonesia, gagasan ini direspon kuat dengan wacana kuota $30 \%$ perempuan di jajaran legislatif. Alasannya, adalah untuk menjamin perempuan sebagai kelompok rentan yang memiliki kepentingan berbeda seperti kesehatan reproduksi dan seksual. Namun sepertinya gerakan-gerakan ini juga kembali menarik paham universal dalam kelompok perempuan itu sendiri. Gerakan-gerakan 
Jurnal Pemikiran Sosiologi Volume 1 No. 2, 2012

Politik Pengakuan Perempuan dengan Disabilitas Pasca Bencana Gempa di Yogyakarta

Fina Itriyati dan Desintha Dwi Asriani

perempuan sedikit mengabaikan bahwa perempuan juga terdiferensiasi lagi ke dalam beberapa jenis seperti perempuan dengan disabilitas. Dalam beberapa hal atau pada konteks kesehatan reproduksi misalnya, seluruh perempuan memang dapat dikatakan memiliki kebutuhan yang berbeda dengan laki-laki. Namun ternyata porsi atau besaran kebutuhan setiap perempuan berbeda dan inilah yang penting untuk menjadi perhatian serius agenda perjuangan perempuan yang belum final tersebut.

Butler sebetulnya dapat menjadi harapan untuk mendekatkan pendekatan-pendekatan feminisme untuk membedah tentang kehidupan perempuan dan disabilitas. Dalam bukunya Bodies That Matter, berbagai macam penjelasan bahwa konsepsi tubuh merupakan wilayah yang sangat politis dalam menerjemahkan identitas manusia. Bagi Butler (1993), tubuh merupakan sebuah hasil ciptaan yang berulang-ulang dipertontonkan untuk sampai pada asumsi tentang kebenaran. Proses ini dianggap tidak dapat menjelaskan tentang pangkal dari kelahiran sebuah tubuh sebagai sebuah definisi yang sebenarnya. Tubuh akan bertahan sebagai sebuah bagian dari kehidupan hanya jika memiliki label gender tertentu seperti laki-laki atau perempuan dimana seseorang akhirnya kehilangan makna individunya dalam menentukan pilihannya. Pendekatan tentang konsep tubuh ini sebetulnya menarik untuk dijadikan landasan berfikir dalam menjelaskan perempuan dengan disabilitas bahwa ternyata dimensi tubuh setiap perempuan itu tidak hanya berhenti pada identitas perempuan yang dilekatkan sebelumnya. Namun mereka mengalami akumulasi pengalaman yang akhirnya menempatkan mereka untuk menyandang status perempuan dengan disabilitas, sama dengan perempuan yang lesbian atau perempuan yang waria. Namun, lagi-lagi Butler juga tidak secara eksplisit mengakomodir fenomena lain di luar variasi identitas perempuan-perempuan yang lesbian atau waria tersebut. Argumentasinya berhenti pada perdebatan tentang keberadaan perempuan dalam relasi heteroseksual dan homoseksual.

Oleh karena itu Thomson (2002) menggarisbawahi untuk perlunya menghadirkan kelengkapan studi feminis dengan mempertimbangkan keberadaan perempuan dengan disabilitas. Teori yang dinamai dengan Feminist Disability memiliki misi besar untuk melampaui topik-topik umum disabilitas yang cenderung terbatas pada penyakit (illness), kesehatan (health), kecantikan, genetik, usia, dan teknologi reproduksi. Lebih jauh, Feminist Disability akan lebih menfokuskan pada perempuan yang mengkaitkan konsep tubuh, politik, medikalisasi tubuh, multikulturalisme, seksualitas, konstruksi sosial atas identitas dan komitmen untuk integrasi (Thomson, 2002).

\section{Politik Pengakuan Perempuan dengan Disabilitas: Transformasi Disabilitas Model Individu ke Model Sosial}

Perempuan dengan disabilitas korban gempa mampu mengartikulasikan kepentingan kelompok disabel secara umum di Yogyakarta. Perempuan yang sejak kecil disosialisasikan untuk bisa bertahan dalam kondisi apapun ternyata membuktikan bahwa mereka tidak hanya bisa bertahan saja tetapi mampu merubah konstruksi sosial dalam 
Jurnal Pemikiran Sosiologi Volume 1 No. 2, 2012

Politik Pengakuan Perempuan dengan Disabilitas Pasca Bencana Gempa di Yogyakarta

Fina Itriyati dan Desintha Dwi Asriani

masyarakat dalam memandang disabilitas, setidaknya di lingkungan tempat tinggal mereka. Dengan hadir sebagai penyandang disabilitas baru, mereka memberikan perspektif baru dalam masyarakat bahwa keberagaman merupakan keniscayaan termasuk keberagaman dalam hal fisik sehingga masyarakat tidak lagi terkotak dalam kriteria normalcy bahwa yang memiliki kondisi fisik berbeda dengan yang umumnya dimiliki oleh anggota masyarakat dianggap sebagai tidak normal. Kriteria tersebut sejak lama menghegemoni masyarakat sehingga anggota masyarakat dengan disabilitas cenderung disembunyikan oleh keluarganya, seolah-olah dilindungi supaya tidak menjadi bahan ejekan di lingkungan sekitarnya dan tidak pantas untuk disejajarkan sama dengan anggota masyarakat lainnya. Kini, dalam konteks perjuangan perempuan, tidak hanya kesetaraan dengan laki-laki saja yang diperjuangkan tetapi juga bagaimana mengakui derajat dan martabat perempuan disabel tidak hanya dalam konteks kultur androsentris tetapi mengakui keberadaan perempuan tersebut dalam konteks pergaulan yang heterogen (Lugones and Spelman 1983; Spelman 1988 dalam Baum, 2004).

Dalam studinya, Henriatta Moore (dalam Baum, 2004) menyebutkan bahwa mengakui perbedaan tidak hanya sekedar mendiamkan keberbedaan itu terjadi, tetapi realisasi dari pengakuan itu juga harus diwujudkan yaitu transformasi sosial dalam konteks dimana kelompok masyarakat hidup. Dalam konteks perempuan korban gempa, keberadaan mereka menjadi pembelajaran bagi masyarakat di Bantul, Klaten dam Yogyakarta bahwa ada perbedaan lain selain perbedaan budaya, agama, etnis, dan jenis kelamin. Sebelum gempa terjadi, masyarakat menganggap mereka penyandang disabilitas adalah anggota masyarakat yang terbelakang, tidak beruntung dan tidak menganggap masalah disabilitas adalah masalah sosial. Mereka menganggap masalah disabilitas adalah masalah individu disabel dan keluarganya sehingga tidak layak untuk dicampuri. Bahkan stigma yang berakar kuat dalam masyarakat masih menganggap bahwa menjadi atau terlahir sebagai disabel merupakan hukuman dari Tuhan sehingga mereka dan keluarganya layak menjalani penderitaan tersebut di dunia. Cara pandang moral model tersebut kemudian bergeser setelah gempa terjadi. Perempuan yang porsinya lebih banyak menjadi penyandang disabilitas karena gempa mampu menggerakkan aktivitas dalam DPO (Disabled People Organization) yang banyak tersebar di Bantul dan Yogyakarta. Mereka mampu terus menjalankan aktivitas dalam organisasi karena sudah terbiasa melakukan multitasking meskipun mereka juga punya tanggung jawab bekerja dan merawat keluarganya. Salah satu informan yang juga salah satu Ketua DPO mengatakan:

"Secara presentase ibu-ibu disabel punya SDM lebih bagus daripada bapak-bapak disabel. Mereka rata-rata lulusan SMA, sementara bapak-bapak hanya lulusan SD. Melihat kemampuan mereka, maka pantas kalau jadi ketua. Karena ibu-ibunya punya lumayan banyak waktu, sedangkan bapakbapak kerja untuk kehidupan ekonomi sehingga jarang bisa aktif dalam organisasi. Yang jelas, kalau ibu-ibu pendidikannya tinggi sehingga bisa organisasi tetap bisa jalan sampai sekarang." 
Keterlibatan perempuan dalam organisasi disabilitas ternyata tidak hanya memberi pembelajaran bagi masyarakat akan keberbedaan, tetapi mampu merubah perspektif medikalisasi atau perspektif individual model disabilitas menuju ke perspektif sosial model disabilitas. Cara pandang medical model yang juga disebut sebagai individual model melihat disabilitas dari sudut pandang medis (kesehatan). Cara pandang ini mendefinisikan disabilitas sebagai sebuah kelemahan fisik dan mental yang berakibat pada keterbatasan individu dalam melakukan aktivitas sehari-hari. Medical atau individual model memahami disabilitas sebagai personal tragedy atau kecelakaan individu yang harus disembuhkan seperti orang normal lainnya dalam kacamata medis. Para dokter, perawat kesehatan dan ahli terapi fisik adalah kelompok yang memiliki kekuasaan dalam menentukan keputusan dan kebijakan atas kehidupan para penyandang disabilitas. Dari sini muncul ide pembangunan Pusat Rehabilitasi Medik yang tujuannya adalah menormalisasi tubuh pasien sehingga bisa mendekati normal. Akibatnya mereka justru tereksklusi dan frustasi karena proses penormalan yang menyakitkan dan terjadi pengabaian hak mereka untuk tetap menjadi disabel. Seolah-olah yang tidak berusaha menjadi normal dianggap sebagai disabel yang malas, tidak mau belajar dan putus asa. Padahal untuk kembali menjadi normal jelas tidak mungkin sehingga proses normalisasi hanya membuat frustasi berkepanjangan, rendah diri dan menjadikan kelompok disabel seperti objek yang bisa menjadi bahan intervensi dan percobaan dokter kapan saja. Salah seorang informan mengatakan bahwa:
"Saya selalu diberi alat-alat dan kursi roda baru dari lembaga baik itu lokal dan internasional. Saya selalu menerima bantuan-bantuan tersebut tetapi kenyataannya tidak saya pakai, karena kursi roda itu yang dikatakan lebih mempermudah kita untuk melakukan mobilitas ternyata justru membuat tubuh kita mudah lelah dan menyulitkan saya untuk melakukan aktivitas pribadi dengan mandiri"

Cara pandang medis dam individual ini oleh Michael Oliver (1996) kemudian dibantah dan membuat paradigma baru dalam melihat disabilitas yaitu paradigma social model dimana disabilitas dilihat sebagai persoalan sosial yang menyangkut masalah sistem ekonomi, kebijakan, prioritasi terhadap sumber daya, soal kemiskinan, pengangguran, dan sistem pelayanan medik yang sudah dilakukan oleh masyarakat sejak lama terhadap penyandang disabilitas. Masalah dasar yang dhadapi oleh penyandang disabilitas dalam paradigma ini adalah rendahnya pengakuan atau penerimaan masyarakat terhadap keberadaan penyandang disabilitas sebagai bagian intergral dari kehidupan masyarakat. Adapun bentuk nyata dari permasalahan yang dihadapi oleh panyandang disabilitas adalah tidak meratanya distribusi atau akses teknologi, asistensi terhadap penyandang disabilitas yang masih menggunakan paradigma medik, tidak adanya pencitraan yang baik di media massa dan penempatan penyandang disabilitas dalam pusat rehabilitasi. Lebih jauh oleh Maduqi (2011) dijelaskan bahwa paradigma social model ini 
Jurnal Pemikiran Sosiologi Volume 1 No. 2, 2012

Politik Pengakuan Perempuan dengan Disabilitas Pasca Bencana Gempa di Yogyakarta

Fina Itriyati dan Desintha Dwi Asriani

memandang persoalan penyandang disabilitas secara utuh dan menyeluruh sehingga pandangan ini banyak dianut oleh para aktivis disabilitas di seluruh dunia. Penempatan disabilitas sebagai persoalan kolektif masyarakat telah merangsang berkembangnya gerakan sosial penyandang disabilitas di banyak negara tidak terkecuali di Indonesia. Sosial model tersebut oleh Oliver (1996) digambarkan sebagai berikut:

\section{Disability Model}

\begin{tabular}{|l|l|}
\hline The Individual Model & The Social Model \\
\hline $\begin{array}{l}\text { Personal tragedy theory } \\
\text { Personal problem } \\
\text { Individual treatment }\end{array}$ & $\begin{array}{l}\text { Social oppression theory } \\
\text { Social problem } \\
\text { Medicalisation }\end{array}$ \\
Social action \\
Self help \\
Individual and collective \\
Expertise & responsibilities \\
Adjustment & Experience \\
Individual identity & Affirmation \\
Prejudice & Collective identity \\
Attitudes & Discrimination \\
Care & Behaviour \\
Control & Rights \\
Policy & Choice \\
Individual adaptation & Politics \\
& Social change \\
\hline
\end{tabular}

Sumber: Michale Oliver dalam 'Understanding Disability: From Theory to Practice', Palgrave (1996)

Bagaimana kualitas hidup penyandang disabilitas terutama kaum perempuan setelah 6 tahun gempa dan bagaimana aktivitas mereka dalam mengadvokasi perempuan disabel lainnya membawa keuntungan bagi gerakan penyandang disabilitas secara umum daerah Bantul, Klaten dan Yogyakarta. Jika melihat perjuangan meningkatkan kualitas hidup mereka masih sebatas pada pemenuhan kebutuhan dasar, tetapi mereka mulai bertransformasi dengan mengekspresikan kepentingan dan hak-hak individual mereka secara kolektif. Pengusahaan akan terpenuhinya hak-hak sosial dan sipil tersebut merupakan tindakan yang membawa perubahan yang sangat berarti bagi disabel lain secara keseluruhan. Berikut komentar salah satu informan:

"Kalau di Pleret semuanya relatiflebih mudah bagi disabel. Disini kan ada kelompok DPO namanya Barakah ketuanya Mbak Purwanti beliau pinter sekali. Beliau pernah mengadakan pertemuan antar DPO dengan Pemerintah Desa, Pemerintah Kecamatan dan dengan Pemerintah Kabupaten Bantul yaitu Dinas Sosial. Dalam pertemuan tersebut dicapai kesepakatan bahwa kegiatan DPO dimasukkan ke dalam agenda Musrenbangdes. Alhamdulillah sudah gol sehingga kemarin desa di Pleret dana stimulan untuk DPO Barokah. Harapan saya bisa ditindaklanjuti kelompok-kelompok lain karena yang nama-nya mengurusi orang cacat bukan tugas kita semata"

Perjuangan gerakan mereka tentu saja tidak semudah membalikkan telapak tangan karena stigma negatif yang kuat terhadap penyandang disabilitas tidak mudah dihilangkan dari benak masyarakat. Dengan prestasi-prestasi kecil di tingkat desa, mereka mulai membangun citra positif mengenai penyandang disabilitas dan ini menguntungkan bagi kondisi penyandang disabel secara keseluruhan. Mereka yang dulunya 
Jurnal Pemikiran Sosiologi Volume 1 No. 2, 2012

Politik Pengakuan Perempuan dengan Disabilitas Pasca Bencana Gempa di Yogyakarta

Fina Itriyati dan Desintha Dwi Asriani

tersembunyi dalam ruang-ruang kotak di rumah mereka mulai berani coming-out dan bergabung dalam aktivitas sosial di DPO. Aktivitas-aktivitas yang beragam dalam DPO yang banyak tersebar di Bantul, Klaten dan Yogyakarta disabel juga mulai diakui oleh pemerintah sehingga mereka bisa secara langsung mengkases dana dari pemerintah yang sebelumnya dimonopoli oleh YPCI (Yayasan Penyandang Cacat Indonesia). Seorang aktivis salah satu LSM disabilitas yang bernama Nina mengakui bahwa jalan panjang bagi kesetaraaan masih panjang tetapi ada optimisme bagi perjuangan gerakan perempuan disabel di daerah Yogyakarta dan sekitarnya karena makin banyak perempuan yang terlibat dalam advokasi bagi disabel perempuan mengingat perempuan sangat rentan pelecahan, penindasan dan kekerasan. Dalam hal seksualitas mereka juga masih terpinggirkan artinya belum dibahas dalam diskursus gender dan seksualitas. Padahal banyak miskonsepsi mengenai dinamika perempuan dengan disabilitas dan seksualitas. Pemahaman bahwa mereka aseksual dan tidak produktif sama sekali tidak benar. Banyak yang masih bisa melakukan aktivitas seksual dan secara biologis produktif tetapi wacana umum menganggap mereka sebagai makhluk tidak utuh, aseksual dan tidak mempunyai gairah. Menurut aktivis tersebut, pendidikan mengenai disabilitas dan seksualitas sangat diperlukan terutama untuk memberikan kenyamanan bagi penyandang disabilitas dan meluruskan stigma yang selama ini melekat pada diri mereka. Dalam wawancara dengan aktivis tersebut didapat informasi mengenai perjuangan mereka:

"Ya sedikit-sedikit mbak kita melakukan advokasi ke lembaga-lembaga advokasi perempuan seperti Rifka Annisa supaya mereka juga mengerti bahwa ada eksklusi jika menganggap semua perempuan kondisinya sama. Harus ada pembahasan dan penanganan yang berbeda jika berbicara mengenai perempuan dengan disabilitas."

Selain itu, perjuangan bagi pengakuan kelompok perempuan dengan disabilitas adalah perjuangan supaya mereka bisa melakukan mobilitasfisik secara mandiri, coming out dan berpartisipasi dalam kegiatan di masyarakat. Selain itu, akses terhadap jaminan kesehatan terhadap penyandang disabilitas merupakan prioritas utama dari gerakan ini. Anggota-anggota dalam DPO selalu dimotivasi tetap bertahan dalam aktivitas di DPO supaya mereka tidak tersembunyi dalam pergaulan di masyarakat. Mereka tetap berupaya supaya masyarakat umum terbiasa melihat dan bergaul dengan disabel sehingga tidak pernah luput dari pelibatan pengambilan keputusan dan lain-lain. Mereka juga berupaya mengatasi masalah hambatan dalam hal akses ke lapangan pekerjaan dan lain-lain. Meskipun sangat sedikit dari mereka yang bekerja di ranah publik tetapi beberapa yang berhasil masuk menjadi dalam industri service seperti menjadi operator telepon hotel berbintang, menjadi manajer proyek di LSM lokal maupun internasional dan lain-lain. Pengakuan akan hak sipil mereka juga dibuktikan dengan diijinkannya secara resmi bagi penyandang disabilitas untuk mengendarai sepeda motor roda tiga dengan dikeluarkannya SIM D untuk mereka.

Perjuangan bagi pengakuan tersebut tidak hanya terhenti pada advokasi dalam mengakses asuransi kesehatan, bantuan pemerintah, tetapi juga 
Jurnal Pemikiran Sosiologi Volume 1 No. 2, 2012

Politik Pengakuan Perempuan dengan Disabilitas Pasca Bencana Gempa di Yogyakarta

Fina Itriyati dan Desintha Dwi Asriani

pengakuan dalam kancah pergaulan secara umum, bagaimana masyarakat menyadari keberadaan disabel sama eksisnya dengan mereka yang bukan disabel. Saat ini, pengakuan yang sedang diperjuangkan oleh perempuan dengan disabilitas secara khusus dan penyandang disabilitas secara umum adalah bagaimana mereka mengatasi masalah utama yaitu dalam mengakses fasilitas publik dan mengkampanyekan bagi pembangunan infrastruktur yang ramah disabel. Di India, dalam struktur patriarki yang begitu kuat dan dogma agama yang sangat kental, kondisi disabel perempuan lebih buruk kondisinya. Hak disabel hanya bisa diraih oleh mereka dari golongan elit saja, misalnya mereka yang bisa mengakses perjalanan udara, hotel berbintang dan parkir mobil khusus disabel yang notabene hanya sedikit dari populasi disabel di India yang bisa mengaksesnya. Dari pengalaman tersebut, sosialisasi dan solusi yang diperlukan bagi gerakan perempuan dan disabilitas tidak hanya melokasi disabilitas hanya sebatas persoalan tubuh saja tetapi melihat disabel sebagai model sosial yang melihat kelompok tersebut sebagai kelompok tertindas dalam masyarakat dan menuntut bagi perubahan sosial (Ghai, 2002).

\section{Penutup}

Tulisan ini merupakan elaborasi awal mengenai aktivisme perempuan disabel korban gempa dan sejauh mana kualitas hidup mereka pasca tahapan rekonstruksi dan rehabilitasi. Bagaimana dan sejauhmana kesuksesan mereka dalam mencapai peningkatan taraf hidup mulai dari tahapan being, belonging dan becoming masih memerlukan elaborasi lebih lanjut. Mulai dari 'being' bagaimana terpenuhi kebutuhan kesehatan fisik, psikologis dan spiritual menuju Belongingyaitu bagaimana mereka terpenuhi kebutuhan dalam mengakses lingkungan fisiknya, pelayanan sosial, pekerjaan dan pendapatan serta yang paling penting adalah 'becoming' bagaimana mereka bebas dan mandiri dalam melakukan aktivitas keseharian, mempunyai waktu dan kondisi yang nyaman bagi peningkatan pengetahuan dan ketrampilannya.

Aktivitas perempuan disabel korban gempa dalam perjuangan bagi kesetaraan perempuan dan disabel secara umum mencapai hal-hal yang sebelumnya tidak tersentuh oleh penyandang disabilitas mulai berkurangnya stigma terhadap penyandang disabilitas secara umum, akses terhadap hak sipil, sosial dan politik serta pengakuan dari masyarakat akan hadirnya mereka di tengah pergaulan yang heterogen. Gerakan perempuan disabel pasca gempa mampu menginspirasi bagi perjuangan kelompok tertindas lainnya bahwa perjuangan bagi kelompok tertindas harus mampu melampaui perspektif yang sudah mapan dalam hal ini perspektif medis, individual dan material menuju ke perspektif yang obyektif dan model sosial dimana terdapat perjuangan terhadap hak sipil, politik dan sosial yang sifatnya kolektif. 'Discredited social stigma' (stigma yang tidak bisa disembunyikan) menurut istilah Goffman dan coming out yang dilakukan oleh penyandang disabilitas ternyata justru bisa pelan-pelan melepaskan mereka dari stigma negatif sebagai penyandang disabilitas. Dari situ keadilan sosial, inklusivitas, partisipasi, pengakuan dan legitimasi dengan sendirinya juga akan berproses menuju level yang lebih maksimal. DPO sebagai 'body' sangat bermanfaat sebagai alat 
Jurnal Pemikiran Sosiologi Volume 1 No. 2, 2012

Politik Pengakuan Perempuan dengan Disabilitas Pasca Bencana Gempa di Yogyakarta

Fina Itriyati dan Desintha Dwi Asriani

untuk mengakses hak sosial dari pemerintah seperti jaminan kesehatan, dan mendapatkan kepastian dalam mendapatkan hak sipil seperti pengurusan KTP, SIM dan hak memilih dan mendapatkan akses dalam pemilihan umum. Nancy Fraser seorang tokoh politik pengakuan mengatakan bahwa dalam pengakuan yang penting tidak hanya promosi terhadap perbedaan tetapi bagaimana redistribusi sumber daya itu juga berjalan sehingga ada kombinasi antara cultural politics of difference dengan social politics of equality. Itu yang akan selalu diperjuangkan oleh para pejuang perempuan dimanapun berada.

\section{Daftar Pustaka}

Andriani, N.S (2011). 'Kesehatan Reproduksi Perempuan Disabel Baru: Sebuah pengalaman pendampingan perempuan korban gempa bumi'. Dalam M. Hasbie (Ed.), Seksualitas dan Kesehatan Reproduksi Perempuan dengan Disabilitas. Jakarta: Yayasan Jurnal Perempuan: hal 89-99

Baum, B. (2004). Feminist politics of recognition. Signs, Vol 29, No.4 (Summer 2004), pp. 1073-1102., http://www.jstor.org/stable/10.1086/382630 Diakses tanggal 9 Januari, 2012

Beckett, A.E. (2006). Citizenship and Vulnerability: Disability issues of social and political engagement. New York: Palgrave Mac Millan

Budisusila, A. (2007). 'Bencana dan Kehidupan Berkelanjutan'. Dalam Widyanta. A.B (Ed.), Kisah kisruh di tanah gempa: catatan penanganan bencana gempa bumi YogyaJateng 27 Mei 2006 Yogyakarta: Cindelaras Pustaka Rakyat Cerdas: hal. 215-238

Candace, W. \& Zimmerman, Don, H. (1987). Gender and Society. http://links.jstor.org/sici?sici. Diakses 8 September 2010.

Denise, B. D. (1999). 'Gender and Family Relation'. Dalam Saltzman (Ed.), Handbook of the Sociology of Gender. Texas: University of Houston Texas, Springer.

Elizabeth, E. M. (1999). 'Gender and Politics'. Dalam Saltzman (Ed.), Handbook of the Sociology of Gender. Texas: University of Houston Texas. Springer.

Fatimah, D. (2007). 'Yang Sering Terabaikan: Gender dan Anggaran dalam Bencana'. Dalam Widyanta. A.B (Ed.), Kisah Kisruh di Tanah Gempa: Catatan penanganan bencana gempa bumi Yogya-Jateng 27 Mei 2006. Yogyakarta: Cindelaras Pustaka Rakyat Cerdas: 433-450

Garland,T.R.(2002). 'Integrating Disability, Transforming Feminist Theory'. Feminist Disability Studies Vol 14 No 3. The John Hopkins University Press. http://www.jstor.org/stable/4316922. Diakses 26 September 2012.

Ghai, A. (2002). 'Disabled women: an Excluded Agenda of Indian Feminism'. Hypatia, Vol 17, No.3 (Summer 2002): 49-66. http://jstor.org/stable/3810795. Diakses tanggal 16 Oktober, 2012 
Jurnal Pemikiran Sosiologi Volume 1 No. 2, 2012

Politik Pengakuan Perempuan dengan Disabilitas Pasca Bencana Gempa di Yogyakarta

Fina Itriyati dan Desintha Dwi Asriani

Jacobs., K.J(1999). Gender and Health Status: Handbook of the Sociology of Gender. Texas: University of Houston Texas, Springer.

Judith, B. (1993). Bodies That Matter. New York: Routledge.

Masduqi, B.F. (2011). 'Kecacatan: dari Tragedi Personal Menuju Gerakan Sosial'. Jurnal Perempuan, Vol 65: $p p$ 17-29.

Meekosha, H. (2002). 'Virtual Activist? Women and the Making of Identities of Disability'. Hypatia, Vol 17, No.3 (Summer 2002), pp. 67-88.

Oliver, M. (1996). Understanding Disability from Theory to Practice. New York: Plagrave

Philips, D. (2006). Quality of Life. London and New York: Routledge

Saltzman, C.J. (1999). Handbook of the Sociology of Gender of Sociology. Texas: University of Houston Texas. Springer.

Thomas, J.G(2000). 'Theory of Disability and Gender'. Feminism at Millennium Vol 25 No.4. University of Chicago Press. http://www.jstor.org/stable/3175525. Diakses 25 September 2012. 